Summer 2009

\title{
Multilayered Governance, Pluralism, and Moral Conflict
}

Thomas Cottier

University of Bern

Follow this and additional works at: https://www.repository.law.indiana.edu/ijgls

Part of the International Law Commons, Law and Politics Commons, and the Legal Ethics and Professional Responsibility Commons

\section{Recommended Citation}

Cottier, Thomas (2009) "Multilayered Governance, Pluralism, and Moral Conflict," Indiana Journal of Global Legal Studies: Vol. 16 : Iss. 2 , Article 12.

Available at: https://www.repository.law.indiana.edu/ijgls/vol16/iss2/12

This Symposium is brought to you for free and open access by the Law School Journals at Digital Repository @ Maurer Law. It has been accepted for inclusion in Indiana Journal of Global Legal Studies by an authorized editor of Digital Repository @ Maurer Law. For more information, please contact rvaughan@indiana.edu.

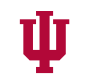

JEROME HALL LAW LIBRARY

$$
\text { INDIANA UNIVERSITY }
$$

Maurer School of Law
Bloomington 


\title{
Multilayered Governance, Pluralism, and Moral Conflict
}

\author{
Thomas Cottier*
}

\begin{abstract}
The quest for multilayered governance faces the problem of endemic tensions and disagreements in international relations and doubts as to whether nations truly share common values upon which an international society can be solidly built. Values, however, are equally controversial within the nation-state. We find similar tensions within domestic and regional layers of governance. In any system of governance, diverging and competing values are inevitable. There are differences in degree, but not in principle, when comparing traits of domestic and international governance. Legal experience in the fields of human rights and international trade regulation indicates that under such conditions, procedures are of prime importance. On all levels alike, procedural instruments and guarantees play a key role in arbitrating between competing values, interests, and rights. These guarantees today are unevenly developed, not only in comparing different layers of government, but also foremost in comparing different countries forming part of the international system. They are far from perfect, but offer the way forward for further work toward a coherent legal theory of multilayered governance.
\end{abstract}

* Professor of European and International Economic Law, University of Bern, Switzerland; Managing Director, World Trade Institute, National Centre of Competence in Research (NCCR) Trade Regulation. I am indebted to Anthony McGrew, Ulrich K. Preuss, Michael Rosenberg, and Beth Simmons for comments on an early draft of the paper prepared for the NCCR Kandersteg Workshop, held January 18-19, 2008, and to Katja Gehne, Rachel Liechti, Julia Meyer, Karolina Milewicz, Anne Peters, and Marion Panizzon for their valuable comments and suggestions. I am particularly grateful to Manfred Elsig for his advice on international relations theory. All imperfections and shortcomings remain my own responsibility.

Indiana Journal of Global Legal Studies Vol. 16 \#2 (Summer 2009)

OIndiana University Maurer School of Law - Bloomington 


\section{INTRODUCTION}

Regulatory matters are increasingly and simultaneously dealt with in both domestic and international law. They involve shared responsibilities of local and central government. In addition, they may be informed and addressed by norms of international law. This constellation of multiple responsibilities in regulatory matters is perhaps most advanced in Europe with the European Union and its solid layer of regional law of integration, but it is a trait shared world-wide with cooperation increasing in almost all fields of law. The principles and rules of the World Trade Organization (WTO) and other instruments of trade regulation form part of an emerging system of multilayered governance whose different regulatory levels interact in a mutually supportive, or sometimes conflicting, manner. Contemporary challenges in the process of globalization, in particular climate change mitigation and the financial breakdown of 2008, will further enhance the need for shared regulations, cooperation, and interaction of domestic and international law. These challenges are difficult to meet by taking recourse to the traditional divide of domestic and international law.

The framework has reached its limitations. Many states continue to operate under dualist traditions, which treat international law and domestic law as two distinct and separate realms. Subjects of law, and standing before institutions, are defined differently in these states. Even in monist traditions, the direct effect of international law in domestic law is often denied, and the two spheres end up being artificially separated. ${ }^{1}$ While international law affects people, the people often cannot invoke it or rely upon it. Contemporary and future challenges of globalization therefore call for an intellectual framework that allows the classical division to be overcome and brings about a more coherent and rational interaction of different regulatory layers, including international law and global relations. This is essentially what the doctrines of multilayered governance and constitutionalization of international law seek to bring about.

Legal scholars working on constitutional approaches to international law and the doctrine of multilayered governance encompassing local, subnational, regional, and global levels of governance face severe theoretical and practical objections. It is argued that underlying values and morality strongly differ among nations and societies and therefore do not offer a solid foundation for common, international legal

1. Thomas Cottier \& Krista Nadakavukaren Schefer, The Relationship Between World Trade Organization Law, National and Regional Law, 1 J. INT'L Econ. L. 83, 120 (1998). 
structures. ${ }^{2}$ It is further argued that pluralism and cultural diversity around the globe imply that a particular moral consensus exists within a given state, nation, people, or civilization. However, it cannot extend to an international society at large. ${ }^{3}$ These values are best protected within the state. ${ }^{4}$ Once we move beyond borders, we enter moral conflict as different societies pursue different purposes. The morality of international law is profoundly distinct from domestic systems with their own principles of international conduct. ${ }^{5}$ Moral and legal obligations relating to fairness and justice incurred behind the veil of ignorance within a society cannot be extended to other countries and the globe for similar reasons. ${ }^{6}$ The lack of common values renders futile all efforts at comprehensive regulation and at defining hierarchies in what remains a highly fragmented world of legal relations. ${ }^{7}$ The early school of realists denied the existence and impact of morality in international relations and considered recourse to it as a matter of exercising power. ${ }^{8}$ This tradition, shaped by the experiences of World War II and the Cold War, is still reflected in contemporary writing. ${ }^{9}$ Attempts to build global structures are, therefore, deemed to be flawed, vain exercises in idealism and legalism. For such reasons, it is argued and held that international law remains clearly distinct from the body of national law. ${ }^{10}$ Unlike domestic law, it is said to lack any police power. ${ }^{11}$ It is effective, the argument goes,

2. For a very careful analysis and discussion, see Andrew Hurrell, On Global Order: Power, Values, and the Constitution of International Society 10 (2004).

3. Samuel P. Huntington, The Clash of Civilizations and the Remaking of World Order 54-55 (1997).

4. Hedley Bull, The Anarchical Society: A Study of Order in World Politics 24041(1977).

5. Terry Nardin, Law, Morality, and the Relations of States 241 (1983).

6. John Rawls, The Law of Peoples Revisited with "The Idea of Public Reasons RevisITED" 171 (1999).

7. Andreas Fischer-Lescano \& Gunther Teubner, Diversity or Cacophony?: New Sources of Norms in International Law, 25 Mich. J. INT'L L. 1059, 1068 (2004); see also Gunther Teubner, Recht als autopoietisches System 25-28 (1989).

8. See E.H. Carr, The Twenty Years' Crisis, 1919-1939: An Intronuction to the Study of International Relations 146(1939); Hans J. Morgenthau \& Kenneth W. Thompson, Politics Among Nations: The Struggle for Power and Peace 246-47 (6th ed. 1985) (discussing that they were actually hoping that moral values play a more important role in addressing various security dilemmas; however, their assessment of the times in 1948 explains their stance on values and how these were abused by state leaders); Kenneth Waltz, Man, the State and War: A Theoretical Analysis 38 (1959).

9. E.g., Huntington, supra note 3, at 308-11.

10. Jack L. Goldsmith \& Eric A. Posner, The Limits of International Law 13 (2005).

11. Mireille Hildebrandt, Governance, Governmentality, Police, and Justice: A New Science of Police?, 56 Buff. L. Rev. 557, 578 (2008) (book review). 
only to the extent that it operates on the basis of convergence of interests, coordination of interests, and coercion. ${ }^{12}$ The two cannot merge. Even scholars who have dedicated their lives to the building of international and supranational structures have strong doubts. Eric Stein concludes his analysis of international organizations and democratic legitimacy on the level of international law on a skeptical note, despite a disposition toward further democratization and integration: "[h]owever, in view of the ... persistent, deep-rooted differences in the peoples-cultural-ethnic, economic, and political-there is little evidence that the democracy-legitimacy gap can be filled by 'Great and Desperate Cures' at the global level at any rate."13 On the other hand, he notes that there is ample evidence that "creative, idiosyncratic arrangements commensurate with the respective level of integration are called for in both the national and the international institutions."14 At any rate, it seems the idea of constitutionalization of international law is fundamentally flawed and should not be pursued..$^{15}$ Any work on constitutionalization of international law and multilayered governance must come to grips with such fundamental objections. They must be assessed and examined before any steps in institution-building can be taken.

In Part I, this article argues that this divergence of values is not unique to international relations; it is equally present in a domestic context. Differences are a matter of degree, and not of principle. Hence, institutional structures need not fundamentally differ, and the search for common ground is appropriate in the quest for shared values upon which common structures and procedures can be solidly built. In Part II, this article addresses the foundations of multilayered governance, discussing the implications of human rights and international economic law and identifying a common and shared core. But rather than seeking foundations based upon harmony and shared values alone, Parts III and IV submit that we need to focus legal attention on developing appropriate procedures of decisionmaking and dispute settlement within a future framework of multilayered governance. It is in this respect that agreement and consent remain of prime importance in a pluralist world.

12. Goldsmith \& Posner, supra note 10 , at 12.

13. Eric Stein, International Integration and Democracy: No Love at First Sight, 95 A M. J. INT'L L. 489,534 (2001).

14. Id.

15. See, e.g., Jeffrey L. Dunoff, Constitutional Conceits: The WTO's "Constitution" and the Discipline of International Law, 17 Eur. J. INT'L L. 647, 661 (2005) (discussing those ideas in the context of the WTO). 


\section{Pluralism and Tensions}

\section{A. Differences and Challenges}

The reality of international relations lends support to the view that international relations operate on fundamentally different premises and planes than the domestic political process: all politics are based upon nationality and the framework of national constitutions. Many argue that the public sphere, essential for democracy, is limited to the domestic realm. They look at global affairs mainly from the point of view of nationally-defined interests. ${ }^{16}$ From this perspective, the law is essentially framed on the basis of national constitutions, while international relations are merely subject to weak structures of international law that are devoid of effective mechanisms of implementation and highly dependent upon voluntary compliance. Power, much more than values and morality, plays a significant role and is exercised on the basis of national interests. Governments are accountable to national voters, not the international society at large. Legitimacy is based upon popular sovereignty, while limited to consent in international relations. Consequently, responsibility to protect remains minimal in international law, even in the core field of protecting human lives. Just observe how human rights are constantly violated around the world and how such violations remain without effective responses. They are best protected to the extent that the international standards are absorbed into domestic law. International solidarity is mainly rhetorical and not a reality. The same is true for the global commons. Exploitation of natural resources shows a complete lack of global governance and responsibility. Efforts at combating climate change have remained largely dysfunctional and are driven by national interests to secure access to energy and resources in support of growth and economic welfare. Vested interests loom large and accountability to people is the exception rather than the rule. There are still a large number of authoritarian states not inclined to lend support to democratic values, which are at the heart of good governance. Even in Western nations, existing structures of multilayered governance-in particular those of the European Union, the most advanced project of this kind-are still met with skepticism and barred from adopting the symbols of constitutionalism, which public opinion in most coun-

16. See Robert A. Dahl, Can International Organizations be Democratic: A Skeptic's View, in DEmocracy's Edges 19, 26 (Ian Shapiro \& Casiano Hacker-Cordón eds., 1999). 
tries prefers to limit to the traditional nation-state. ${ }^{17}$ The world is in constant moral, political, and economic conflict. Common values, if they exist at all, are hard to identify.

These arguments supporting relativism may lead to resignation. But they also reinforce the need to seek new and better structures of governance for coming generations and to refine a relationship between global, regional, and domestic law. They are powerful drivers, not in the sense of desperate cures, but as an impulse for processes to move in the right direction. We need a better and universally valid intellectual compass to find appropriate directions for future structures of governance and law.

We should not forget that the state of nature did not prevent Thomas Hobbes from turning to shared and contractual arrangements in order to keep the peace, albeit at a cost to society and individuals. It did not prevent John Locke, Jeremy Bentham, and Baron de la Bréde et de Montesquieu from developing constitutional structures when in law they did not exist at the time. It did not prevent Adam Smith from challenging the deeply entrenched mercantilism in his time. It did not prevent Alexander Hamilton, James Madison, and John Jay from developing principles of federalism when colonialism was dominant. It did not prevent philosophers like Francisco Suarez and Emerich Vattel from developing the foundations of international law. It did not prevent Immanuel Kant from exploring the potential of an international society when reality was far from reaching these ideals. In the twentieth century, it did not prevent world leaders from conceiving the United Nations and the process of European integration, despite a past pointing to the contrary. ${ }^{18}$

The quest for peace has been a strong antidote to realist resignation in the building of nation-states and international law. It is the same quest which today drives the effort toward multilayered governance in a globalized world characterized by instant communication. Realists contribute to stabilizing existing power structures and relations. They are important in terms of reality checks and debate. They sharpen the arguments for, and the foundations of, multilayered governance, the life of international law, and the long-term realization of values shared by all mankind. They ensure that we do not build on shifting sand. But they offer little in terms of improving governance and conditions for the majority of people around

17. Cf. Ernst-Ulrich Petersmann, The 2004 Treaty Establishing a Constitution for Europe and Foreign Policy: A New Constitutional Paradigm?, in Europa und seine Verfassung 176, 182-86 (Charlotte Gaitanides et al. eds., 2005).

18. Paul Kennedy, The Parliament of Man: The Past, Present, and Future of the United NATIONS 25, 26 (2006). 
the world or of addressing common concerns in the process of globalization. The effort is one addressing, and coping with, the huge deficiencies of the Westphalian system of nation-states in the post-colonial and partly post-national era.

\section{B. Shared Problems}

The starting point is a rather trivial observation: tension and conflict are not limited to international relations. They exist on all layers of governance alike: domestic, regional, and international. Theories of international relations, rather than ignoring the fact that disagreement is not unique to international relations and law, should look at the full picture. They should no longer look at the nationstate as a unitary subject and actor. Theories of justice often assume basic coherence in a given society as a basis of democracy, distributive justice, and fairness. ${ }^{19}$ They presuppose a community of shared values, which offers the basis of mutual trust for democracy, delegation of powers, and majority rule. ${ }^{20}$ True, domestic societies, organized on the basis of shared language, education, and culture, offer a wider range of common perceptions, attitudes, and traditions. Yet, values are equally controversial within the nation-state.

We find similar tensions within domestic and regional layers of governance.

19. See, e.g. John Rawls, A Theory of Justice (rev. ed., Oxford Univ. Press 1999) (1971).

20. Anne Peters concisely recalls the argument

that a democracy must be "homogeneous" to be stable, because only then all (or at any rate the vast majority) of the people share a commitment to the state and its democratic regime form, they are tied to their fellow citizens through an understanding of the commonality of their fate and the recognition of equal liberties, and they rank these commitments and loyalties higher than the various cleavages that divide national society. A more psychological explanation why democratic procedures are premised on the faith and trust deriving from fellowship in a core community is that the unpredictability of results, the disappointment of compromise, and the confusion of choices is generally not borne by groups in which the sentiments of commonality and belonging are absent. The ideas of uniformity, fellowship, and collective identity overlap with the quest for a societal "basic consensus." The basic consensus is-so to speak-the uniformity of opinions on the foundational principles of society. It is considered as the pre-requisite of majority decisions, because the basic consensus guarantees the stability of institutions, serves as a guideline for deciding controversial issues, discharges politics on those issues where no vote is needed, and generally triggers the diffuse support of the system by its citizens.

Letter from Anne Peters, Professor of Law, Universität Basel, to author (Dec. 5, 2008) (on file with author). 
Pluralist societies are not rooted in uniform moral perceptions. In any system of governance, diverging and competing values are inevitable. They may be suppressed, but they exist and should be recognized in pluralist societies. The nature of all political debate is disagreement, the pursuit of interests, and the search for common ground. A wide variety of values informs the debate and discourse. All relations, whether domestic or international, are inherently human; differences are differences in degree, rather than principle, and are clearly demarcated.

It is one-sided to conceive of nations and domestic society as harmonious and coherent, while also emphasizing tensions and conflict in international relations. Peace is as much at risk at home as it is abroad. Of the nearly one hundred armed conflicts in the world since 1989, all but five were, or are, internal conflicts, albeit mainly due to the end of the bipolar world that froze ethnic conflict. ${ }^{21}$ These figures suggest that building societies and states on all layers has been, and remains, a longterm process. Cultural homogeneity and political consensus on basic values as an alleged prerequisite for democracy in mature societies is the result of a long-term historical process and experience. Constitutions acquire authority only over time as they produce public goods and welfare. They were generally weak, opposed and even imposed, at the outset when the experiment of new democracy was taken up without a well-established society in place. From a historical perspective, governance has not been static but rather subject to evolution and constant change.

The same applies to international governance. Generally weak at this time, in a world of economic interdependence, it may change and evolve in response to global challenges such as climate change. New communities of shared interest may emerge, forming the foundations for new forms of political culture and democracy on matters vitally relevant to the entire globe. Any start will be difficult, controversial, and contested. This is the nature of political debate. Again, there is no fundamental difference in principle between different layers of governance.

A more detailed examination offers a mixed bag. The achievements of civilization are juxtaposed anarchy, conflict, and even war in all forms of human society. We find a mixture of peace and conflict at local, regional, national, continental, and world-wide levels and relations. This mixture, rather than a clinical separation between the domestic and international realms, offers a realistic starting point from which to assess the issue of shared values and the potential for multilayered governance based upon the rule of law. We cannot draw a fundamental line between the domestic and international realms. Sovereignty cannot separate domestic and inter-

21. KENNEDY, supra note 18 , at 105. 
national life completely. ${ }^{22}$ Domestic and international tensions need to be considered in tandem. Modern and liberal theories of international relations increasingly confirm this proposition. States are not unitary actors. Foreign relations are influenced and shaped by competing values and interests at home. While realism was strongly concerned with national security, the emphasis on international cooperation within international organizations has gradually shifted the focus toward greater accountability in international politics and thus toward constitutional issues, bridging the divide between the domestic and international realms. ${ }^{23}$

\section{Multilayered Governance and Cosmopolitan Values}

\section{A. Emerging Constitutionalism}

\section{The Legal Effort}

Confronted with the challenges of the WTO and of human rights protection, international lawyers set out to assess underlying problems in terms of constitutional theory. ${ }^{24}$ The effort is part of a broader movement to overcome the classical and conceptual division between international and domestic law of the Westphalian system of nation-states and the reconfiguration of states in the process of globalization. ${ }^{25}$ The process essentially comprises the fields of human rights and international economic law. In both areas, a controversial debate on the constitutionalization of

22. See Stephen D. Krasner, Sovereignty: Organized Hypocrisy 20 (1999) (studying the various interactions of international legal sovereignty, Westphalian sovereignty, domestic sovereignty, and interdependence sovereignty).

23. See Alexander Wendt, Social Theory of International Politics 253 (1999); Judith Goldstein \& Robert O. Keohane, Ideas and Foreign Policy: An Analytical Framework, in Ideas and ForeigN Policy: Beliefs, Institutions and Political Change 3, 25 (Judith Goldstein \& Robert O. Keohane eds., 1993); Helen V. Milner, Rationalizing Politics: The Emerging Synthesis of International, American, and Comparative Politics, 52 InT'L Org. 759, 759 (1998); Andrew Moravcsik, Taking Preferences Seriously: A Liberal Theory of International Politics, 51 INT'L ORG. 513, 520 (1997); Robert D. Putnam, Diplomacy and Domestic Politics: The Logic of Two-Level Games, 42 Int'L Org. 427, 455 (1988).

24. See, e.g., Constitutionalism, Multilevel Trade Governance and Social Regulation (Christian Joerges \& Ernst-Ulrich Petersmann eds., 2006); Ernst-Ulrich Petersmann, Constitutional Functions and Constitutional Problems of International Economic Law (1991); Thomas Cottier \& Maya Hertig, The Prospects of 21st Century Constitutionalism, 7 Max Planck Y.B.U.N.L. 261 (2004); Jürgen Habermas, The Constitutionalization of International Law and the Legitimation Problem of a Constitution for World Society, 15 Constellations 444 (2008); Anne Peters, The Globalization of State Constitutions, in New Perspectives on the Divide Between National and International Law 251 (Janne Nijman \& André Nollkaemper eds., 2007).

25. See Transformations of the State? 6 (Stephan Leibfried \& Michael Zürn eds., 2005). 
international law is taking place. While many competing concepts of constitutionalism are employed ${ }^{26}$ and some authors suggest abandoning the term, ${ }^{27}$ the effort shares the common concern of looking at international law and domestic law in a more coherent manner. ${ }^{28}$ Influenced by the traditions of federalism, lawyers and political scientists focus on the interaction and the allocation of powers among different layers of governance. ${ }^{29}$ It is essentially a matter of finding appropriate criteria for the allocation of regulatory powers to, and the balance within, different layers of governance-global, regional, domestic, and local-and defining the proper interaction of these layers within a modern concept of nation-state sovereignty. ${ }^{30}$

These various models of constitutionalization offer an appropriate framework for analysis, without prejudging how powers should ultimately be allocated. The crucial point is to conceive international, regional, and domestic levels as a single and ideally coherent regulatory architecture of multilayered governance. Multilayered governance proposes a process and direction. It does not stand for the idea of world government or a comprehensive world legislature, but it builds upon the interaction and interdependence of the domestic and international spheres, and seeks what Eric Stein called "creative, idiosyncratic arrangements commensurate with the respective level of integration...." Multilayered governance thus requires common foundations applicable to all these layers while at the

26. Efforts comprise three schools of thought. The first school of thought emphasizes mainly informal horizontal and vertical networks of government. For an example of this first school of thought, see Anne-Marie Slaughter, A New World Order 135-51 (2004). The second school of thought discusses global administrative law. See, e.g., Benedict Kingsbury et al., The Emergence of Global Administrative Law, 68 Law \& Contemp. Probs. 15, 27-31 (2005). For a critical appraisal of this second school of thought, see Carol Harlow, Global Administrative Law: The Quest for Principles and Values, 17 Eur. J. INT'L L. 187, 207-11 (2006). The third school of thought involves institutional or public law. For an example, see Armin von Bogdandy et al., Developing the Publicness of Public International Law: Towards a Legal Framework for Global Governance Activities, 9 German L.J. 1375, 1380-81 (2008).

27. Deborah Z. Cass, The Constitutionalization of the World Trade Organization (2005); Robert Howse \& Kalypso Nicolaidis, Legitimacy Through "Higher Law"? Why Constitutionalizing the WTO Is a Step Too Far, in The Role of the Judge in International Trade Regulation 307, 308 (Thomas Cottier \& Petros C. Mavroidis eds., 2006).

28. Cottier \& Hertig, supra note 24, at 263; Thomas Cottier \& Petros C. Mavroidis, Concluding Remarks, in The Role of the Judge in International Trade Regulation, supra note 27, at 349, 353.

29. For a seminal work in political science, see Liesbet Hooghe \& Gary Marks, Unraveling the Central State, but How? Types of Multi-Level Governance, 97 Am. Pol. Sci. Rev. 233, 234 (2003).

30. See, e.g., John H. Jackson, Sovereignty, the WTO, and Changing Fundamentals of International Law (2006); John H. Jackson, Sovereignty-Modern: A New Approach to an Outdated Concept, 97 Aм. J. INr'L L. 782 (2003) [hereinafter Jackson, Sovereignty-Modern].

31. Stein, supra note 13 , at 534. 
same time respecting diversity and pluralism. The framework builds upon observations of legal phenomena - which we perceive in reality-in particular, the increased outsourcing of regulatory and constitutional functions to international law in the process of cooperation and integration. It further develops normative projections as to how relations between different layers of governance should be framed in a coherent and less fragmented manner. It is both analytical and prospective. It increasingly informs the debate on the future of international economic law, ${ }^{32}$ and it offers the potential to render the legal theory truly global and international, leaving behind strong focus on national traditions. ${ }^{33}$

Multilayered governance builds upon the achievements of the Western constitutionalism and federalism of the eighteenth and nineteenth centuries. It essentially draws on the experience gained within the realm of domestic affairs: the protection of human rights and property rights, fairness, equal opportunities, distributive justice, democracy and accountable government, the rule of law, and checks and balances, both horizontal and vertical. Within the wide range of different proposals submitted by scholars, these elements all play a key role in shaping the future of international law and organizations. ${ }^{34}$ Multilayered governance thus relies upon a common and shared body of underlying constitutional values and legal principles, which penetrate all layers of governance alike. Today, these foundations exist in positive international law and are formally shared by the constitutions of a large number of states.

Since World War II, the developments of international law have increasingly absorbed Western traditions of liberalism in advancing the ideals of human rights and of equal conditions of competition in international economic law. ${ }^{35}$ There is no shortage of instruments to which a large majority of states have consented and which they formally share under the auspices of the United Nations and other international organizations. They share common concerns with normative principles and rules in regional and domestic law. Human rights are an ideal common to all layers of governance, and principles of non-discrimination in economic rela-

32. See, e.g., The Future of International Economic Law (John H. Jackson \& William J. Davey eds., 2008).

33. See generally Anne Peters, Die Zukunft der Völkerrechtswissenschaft: Wider den epistemischen

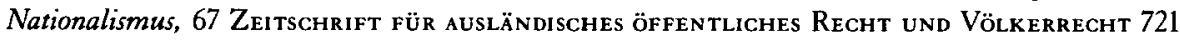
(2007) (ascribing to international law the potential to lead the globalization of legal theory).

34. See, e.g., Daniel C. Esty, Good Governance at the World Trade Organization: Building a Foundation of Administrative Law, in THE Future of In ternational Economic Law, supra note 32, at 71.

35. John Gerard Ruggie, International Regimes, Transactions, and Change: Embedded Liberalism in the Postwar Economic Order, 36 Int'L Org. 379, 382 (1982). 
tions can equally be found at different layers of government, complementing each other. Domestic constitutions and legal orders have been increasingly influenced and shaped by international law. ${ }^{36}$

Human rights overall have the potential to play an important structural role in multilayered governance. This is particularly true for core rights limiting the powers of governments. International law limits such powers in the same way that constitutional rights limit the powers of sub-federal entities. They exert vertical checks and balances and thus form an important ingredient of multilayered governance. Human rights on a global and a regional level offer checks on domestic law, much as constitutional rights monitor legislation of federal and sub-federal entities. The emphasis on past and contemporary protection is clear within constitutional and domestic law. Conceptually, it does not exclude reinforcing protection on the international and regional layers of governance.

In economic law, non-discrimination and equal conditions of competition are basic foundations that express shared values. They stand for the principle of treating foreigners and foreign products no less favorably than domestic subjects and products. They have the potential to become cornerstones of multilayered governance. Historically, both in federal and integrated systems, they were present at the outset of a long-term process, which eventually expanded to include additional policy areas beyond trade regulation. They qualify the principle of sovereign equality of states, and introduce key elements of multilayered governance, as these principles introduce vertical checks and balances against protectionist policies that disregard the interests of those not represented in domestic legislative processes. ${ }^{37}$

Structurally, the principles operate in the same manner as constitutional rights relating to commerce (Wirtschaftsfreiheit, interstate commerce clause) as well as the Four Freedoms and the principle of non-discrimination in European Community (EC) law-which, in turn, operate as vertical checks at other layers of governance. Other than with regard to human rights, protection and enforcement on the international level are stronger. They are subject to the WTO dispute settlement and compliance mechanism. It is at the heart of EC jurisprudence and plays an important role in constitutional law and policy. It is here that multilayered governance is perhaps most advanced, although more work on coherence will be required. The potential to succeed is real, even under existing instruments of positive law.

36. Daniel Thuerer, 1 Kosmopolitisches Stantsrecht 3-40 (2005).

37. Thomas Cottier \& Matthias Oesch, International Trade Regulation: Law and Policy in the WTO, The European Union and Switzerland 346-427 (2005). 


\section{Efforts by International Relations Theory and Moral Philosophy}

Recourse to shared legal rights and obligations in positive law of all or most states is an important and often ignored component in discussing the fundamental problem of shared constitutional values within the international community. It is a major achievement upon which multilayered governance builds. There is ample evidence in positive law and thus of consent, in particular in the United Nations Human Rights Covenants. At the same time, recourse to legal instruments and black letter law is not sufficient. The objections raised in international relations theory and moral philosophy are all rooted in observations looking beyond and behind positive law. Legal instruments may have been imposed and may not reflect true and underlying values and consent upon which society and solid governance is built. The import of Western legal concepts may remain superficial and a matter of convenience, rather than being based on convictions and true beliefs. This is an important point. Law requires underlying values of a given society or community upon which its legitimacy relies. Such legitimacy is essential for the operation and effectiveness of law. Without it, law cannot perform its main function as a stabilizer of legitimate expectations as to human conduct. It is an essential precondition for voluntary compliance, without which legal systems, both domestic and international, fail. ${ }^{38}$ Legitimacy depends upon underlying values, in particular fairness and justice. These values draw upon perceptions of morality, which in turn rely upon traditions, religion, philosophy, culture, and civilization. They inform the law in a dialectical process, which in turn feeds back into moral perceptions.

Are there truly shared moral values beyond borders of traditional polities, based upon a common heritage and human nature? The question is of core interest to constitutional and international lawyers seeking to explore the potential of shared and multilayered governance beyond the nation-state. It is at this point that the issue becomes relevant and crucial for legal architecture. Multilayered governance cannot work without common ethical foundations and shared beliefs. If built in the absence of such values, it will not be sustainable.

The problem of shared values is at the heart of the debate in contemporary moral philosophy and international political theory and the competing schools of thought. ${ }^{39}$ Many of the objections raised above are influenced by realism, which essentially denies the existence and relevance of such values in a power- and interest-driven world,

38. Thomas M. Franck, Fairness in International Law and Institutions 25 (1995).

39. Allen Buchanan, Justice, Legitimacy, and Self-Determination: Moral Foundations for International Law 28-29 (2007); Simon Caney, Justice Beyond Borders: A Global Political Theory 56 (2005); Hurrell, supra note 2, at 85. 
or by an approach perceiving international relations merely as a society of states, rather than of persons. They may be based on cultural relativism or on nationalism, both of which share the denial of underlying values common to all nations.

Universalism, on the other hand, stresses the existence and the normative potential of shared values. It identifies an overlapping consensus of some moral values. ${ }^{40}$ Commonalities are found and normatively argued by cosmopolitan schools. They essentially reflect the liberal and social democratic heritage as applied to transnational constellations. Cosmopolitanism is based upon the premise that all human beings share traits common to the human condition ${ }^{41}$ and essentially are entitled to be treated alike. It is an egalitarian liberal doctrine that emphasizes distributive justice and equal opportunities as the foundation of fairness in international relations. ${ }^{42}$ For Allan Buchanan, human rights provide the normative foundations of international law, legitimacy, and justice. ${ }^{43}$ Cosmopolitanism is a moral and political doctrine that extends to legal and institutional dimensions, seeking to shape international law and global institutions in a manner that will further the goals of moral cosmopolitanism. It is not limited to moral philosophy, but is equally present in international relations theory, prominently expounded by David Held..$^{44}$ It amounts to an important school in political science. Summarizing his book Justice Beyond Borders: A Global Political Theory, Simon Caney characterizes his brand of cosmopolitanism as follows:

This book has attempted to justify an egalitarian liberal brand of cosmopolitanism. It has defended the thesis that there are universal principles against cultural relativists. Its general strategy has been to show that many critiques of universalism mischaracterize it and that other critiques are simply unpersuasive. It has defended two universal principles of justice in particular. First: it defends a liberal package of civil and political human rights, arguing that these are

40. CaneY, supra note 39 , at 25.

41. Kwame Anthony Appiah, Cosmopolitanism: Ethics in a World of Strangers, at xv (2006).

42. See, e.g., Charles Beitz, Political Theory and International Relations 127-61 (1979); see also Frank J. Garcia, Trade Inequality and Justice: Toward a liberal Theory of Just Trade 59-62 (2003); Thomas Pogge, Realizing Rawls (1989); Frank J. Garcia, Global Justice and the Bretton Woods Institutions, in The Future of International Economic Law, supra note 32, at 23, 26 (noting an application of the Rawlsian "Difference Principle" to international economic law).

43. Buchanan, supra note 39 , at $118-90$.

44. See, e.g., David Held, Democracy and the Global Order: From the Modern State to Cosmopolitan Governance (1995); David Held, Global Covenant: The Social Democratic Alternative to the Washington Consensus (2004); David Held, Models of Democracy (2d ed. 1996). 
necessary to respect persons' interests in leading fulfilling lives. In doing so, it chronicled five reasons for thinking that liberal civil and political human rights best enable people to flourish. Second: it defends an egalitarian distributive programme, defending subsistence rights, a principle of global equality of opportunity, rules of fair pay, and a commitment to prioritizing the least advantaged. Furthermore, by contrast with many other cosmopolitans... the argument for these universal principles of distributive justice does not depend on whether there is extensive economic globalization or not.... Drawing on these universal principles of civil, political, and distributive justice, this work then criticized a statist world order and defended a system of global political authorities. ${ }^{45}$

Cosmopolitan schools of thought thus offer hope and a moral foundation upon which multilayered governance can be built into law. Cosmopolitanism recognizes that some human values are universal and shared, while others are culturally specific and local. Overall, the findings support the constitutional idea of multilayered governance and the abolishment of a principled division between domestic and international law. Indeed, Caney develops structures to this effect under the heading of legal or institutional cosmopolitanism. ${ }^{46}$

\section{Lessons from Legal Experience}

There is thus a strong body in philosophical literature, political science and international relations theory supporting the perception of shared values upon which a doctrine of multilayered governance can build. International lawyers are not alone in their quest. Yet, the cosmopolitan school remains highly controversial in light of competing theories. As moral philosophy does not extensively take into account the daily operation of international law, it may be helpful to introduce a proper legal perspective at this point, beyond the recourse to positive law and consent. What can lawyers bring to the table beyond recourse to positive law? What can we learn from the legal experience in assessing the problem of shared values?

The process of law is informed by values, but it is mainly characterized by competing rights and interests. It often faces competing and conflicting values. Law inherently operates in a pluralist environment when it comes to assessing specific and particular problems. This is certainly true for open societies, but also

45. CANEY, supra note 39, at 263-64.

46. Id. at $148-88$. 
under authoritarian rule, albeit to a lesser extent. Even here, in the end, competing interests and values need to be assessed in addressing specific problems. It is certainly true for international law. Some would argue that international law is outright indeterminate in the final analysis. ${ }^{47}$ Outcomes, impact, and realization of values therefore depend largely upon procedural guarantees both in the political process and in judicial dispute settlement. This is true for all layers of governance; it is not limited to the realm of international law and relations. Again, there are differences in degree, but not in principle. The prospects of multilayered governance therefore depend upon the level of shared procedural avenues established at and among different layers of governance.

The legal profession is particularly trained and versed in dealing with diverging interests and opposing views in a given context. It is able to approach problems on the basis of defined procedures. This is particularly true in the courtroom. Procedural fairness and preoccupation with processes are the main tools of the profession in approaching conflicting interests and values alike, leading toward rational decisions and justifications.

The legal experience and Western tradition of procedural fairness equally informs the political process. In an open and liberal society, the latter essentially operates on the basis of critical rationalism, which considers freedom of expression and speech as the single core value upon which basic decisions must be hammered out in a pluralist environment. This takes into account, in a pragmatic manner, different interests which need to be balanced with a view to finding satisfactory solutions to practical problems. ${ }^{48}$ The core contribution of law consists of making available "clear, stable, and transparent procedures" that allow for "predictable decisionmaking." ${ }^{49}$ Contemporary challenges of ensuring sustainability and of balancing ecological, social, and economic interests are all informed by a procedural approach and school familiar to lawyers. ${ }^{50}$ Lawyers, thus, may particularly contribute toward exploring the relationship of values and procedural guarantees.

47. Martti Koskenniemi, From Apology to Utopia: The Structure of International Legal Argument 153-57 (2006).

48. Hans Albert, Traktat über kritische Vernunft 173-82 (3d ed. 1975). See generally Karl Popper, The Open Society and its Enemies (1945).

49. Esty, supra note 34, at 73 (citing Lon Fuller, The Morality of Law (1964)).

50. See generally Marie-Claire Cordonier Segger \& Markus W. Gehring, Introduction to Sustainable Development in World Trade Law 1, 1-22 (Markus W. Gehring \& Marie-Claire Cordonier Segger eds., 2005). 


\section{B. Human Rights Protection}

We now briefly turn to human rights and to equal conditions of competition and property protection in international economic law, which we have identified as being potential cornerstones of multilayered governance. ${ }^{51}$ They all derive from shared principles of liberty, but have been implemented in quite different ways. ${ }^{52}$ They have been adopted and supported for different reasons, as have the values underlying them. They follow different procedures. They often compete with other institutions on an operational level. They are both relevant to multilayered governance to the extent that they offer checks and balances on different layers.

Human rights have been ratified in terms of treaty obligations by a large majority of states. The International Covenant on Civil and Political Rights, as well as the International Covenant on Economic, Social, and Cultural Rights, are practically universal in scope. ${ }^{53}$ Formally, they provide the foundations of universally recognized, and thus shared, values. They are the paradigm of universalism, although not all the rights may be of equal importance to the entire world. It is fair to say that human rights values are shared and agreed upon in principle for all layers of governance alike. They are essential coordinates. Today, they amount to the most deeply anchored principles in law. Nobody seriously argues against them, and the concept is widely accepted, at least as a core. No government can afford to challenge human rights as an ideal. From a cosmopolitan view, there can be no doubt that people share human rights as common ideals, values, and goals. They are the main guarantees and expressions of hope. People have their values, and they do not make a principled difference as to the layer of governance concerned.

The International Covenants essentially address domestic affairs; states are

51. Ernst-Ulrich Petersmann, Constitutional Economics, Human Rights and the Future of the WTO, 58 Aussenwirtschaft 49 (2003); Ernst-Ulrich Petersmann, Human Rights, Cosmopolitan Democracy and the Law of the World Trade Organization, in Foundations and Perspectives of International Trade Law 79-96 (Ian Fletcher et al. eds., 2001); Ernst-Ulrich Petersmann, Morality, Human Rights and International Economic Law: Towards Cosmopolitan Market Integration Law?, in Recht UND Ethos im Zeitalter der Globalisierung 53-86 (H.D. Assmann \& R. Sethe eds., 2004); Ernst-Ulrich Petersmann, Time for a United Nations "Global Compact" for Integrating Human Rights into the Law of Worldwide Organizations: Lessons from European Integration, 13 Eur. J. INT'L L. 621 (2002).

52. See Thomas Cottier, Trade and Human Rights: A Relationship to Discover, 5 J. INT'L Econ. L. 111 (2002).

53. For a comprehensive and recent analysis, see Walter Kaflin \& Joerg Kuenzli, Universeller Menschenrechtsschutz (2d ed. 2008); Christian Tomuschat, Human Rights Between Idealism and Realism 58-83 (2003). For the legal instruments, see Office of the United Nations High Commissioner for Human Rights, International Law, http://www2.ohchr.org/english/law (last visited Feb. 26, 2009). 
under an obligation to treat human beings within their jurisdiction accordingly. Most national constitutions reflect these commitments, and the same is true for contemporary EC law. It is, however, a different matter as to whether these agreements truly reflect a strong commitment of governments around the world, given today's realities of constant abuse and violations. Governments were able to enter these agreements at a very low cost, but it is still an open question to what extent these governments adhere for convenience, with little consequence to the domestic power structures of a system based upon sovereignty of states.

Implementing human rights values in legal orders has been, and remains, difficult. ${ }^{54}$ Human rights offer guidance in domestic policymaking, legislation, and adjudication, but implementation by means of international law remains weak, given widespread authoritarian regimes and frequent allocation of resources for purposes other than protection and promotion of human rights. In practical terms, the Covenants introduce only feeble elements of multilayered governance. This is also partly true for the European Convention on Human Rights, as members are not obliged to implement rulings of the European Court of Human Rights, but are limited to offering compensation to victims of rights violations. Implementation varies among members of the Covenants. It largely depends upon domestic law and legal culture. It has an impact on members based upon western traditions of constitutional law. It is still weak in countries with authoritarian traditions. Importantly, these deficiencies do not relate to the content and scope of rights, but instead to modes and procedures of protection, which vary considerably among different layers of governance and still lack overall coherence. The lack of efficient procedures, however, may be an indication that the rights and underlying values are not truly shared and are not taken seriously by all. Indeed, different agendas are pursued for human rights.

The main function of the Universal Declaration of Human Rights was to overcome the legacy of colonialism and related racism and to loosen the restricting notion of civilized nations in the wake of decolonization. The main obligation to arise from this evolution rested with former metropolitan powers and industrialized nations. ${ }^{55}$ After the trauma of World War II, it was an idealist response to the colonial state, the failure of so-called civilized nations to deal with racial and

54. See generally Human Rights: From Rhetoric to Reality (Tom Campbell et al. eds., 1986).

55. Thomas Cottier, Cosmopolitan Values in International Economic Law: Myths and Realities (Nat'l Ctr. of Competence in Res. Trade Reg., Working Paper No. 22, 2008), available at http://www .nccr-trade.org/ip-1/cosmopolitan-values-in-international-economic-law-myths-and-realities-2.html. 
cultural discrimination and imperialism..$^{56}$ It was an agenda to be primarily applied at home in industrialized nations, and an effort at establishing long-term responsibilities vis-à-vis developing countries in terms of supporting human rights protection around the globe. Much progress has been achieved in combating racial discrimination in industrialized countries. Prejudice has been reduced, often due to constitutional rights and accompanying procedures. Much remains to be done, particularly in an era of increased international migration and global integration. So far, development assistance, incentives in economic policies, and other efforts to build respect for human rights in developing countries have remained modest. Procedural guarantees are lacking. These countries are often left alone with their challenges for financial reasons, and human rights intervention has remained controversial in international law. Developing countries primarily emphasize social and economic rights, including a broad right to development, in order to argue in support of claims for distributive justice and framework conditions in international economic relations conducive to meeting their needs. In return, political and civil rights are considered in relation to the political systems in place, as a matter of domestic affairs, and are protected from foreign intervention under Article 2 (7) of the U.N. Charter.

Human rights policies are thus informed by diverging and competing interests. At the same time, appropriate procedures to address and settle such competition are lacking. This explains the main difficulties encountered in the realization of human rights. Moreover, the relationship to other policies often remains unclear. In international economic law, linkages to human rights have not been fully developed and the two fields were traditionally dealt with in isolation. It is only recently that bridges have been built in legal theory. Much work still lies ahead in building appropriate procedures that allow linking of different policy goals in a particular context.

In assessing these realities and imperfections in light of multilayered governance, it is important to stress that comparable difficulties also exist within states. Difficulties are by no means limited to the international realm. The program of social and economic rights has been controversial in most countries and lies at the heart of the discourse on distributive justice in pluralist societies. Protection of civil and political rights is the object of constant struggle and a stream of case law. Procedures vary and determine the effectiveness of protection. There are wide discrepancies within countries and within different political systems. While some allow for strong legal protection, others do not. Judicial review may simply be excluded or limited, or it may vary for different layers of domestic governance. The Swiss Con-

56. See Edward W. Said, Culture and Imperialism 7 (1994). 
stitution, for example, in principle excludes constitutional review of federal statutes, but allows it for sub-federal acts. ${ }^{57}$ Even in mature democracies, the contours and shaping of human rights protection remains a matter of disagreement, and they struggle as new challenges to freedom and security of individuals arise. This is equally true for the European Union, where the protection of fundamental rights is strongly anchored in the treaty and case law, but constantly competes with other policy goals, in particular fundamental freedoms relating to market access.

The difficulties in implementing human rights on all layers of governance show that they, and the values underlying them, compete with other interests and policy goals, including competing human rights. The problem is not one of underlying values, but of competition of divergent values and interests at stake in a given context. There is wide and considerable disagreement on the question of the extent to which resources should be allocated to these values, both internally and in foreign relations. On all layers, procedures for implementing rights on the operational level are of key importance and determine the extent to which human rights values are translated into reality. Human rights protection still suffers from structural inefficiencies on the international level as well as in most countries. Shared values and rights, in other words, are not yet sufficiently matched in terms of procedural guarantees. Differences exist between different layers of government, but they are differences in degree, and not in principle. The challenge is one of designing appropriate processes and providing checks and balances in multilayered governance.

\section{International Trade Regulation}

\section{Equal Conditions of Competition}

In international trade relations, the WTO principles of non-discrimination constitute the core principles of the international trading system, shared by more than 150 members of the WTO. ${ }^{58}$ In contrast to human rights agreements, these principles do not offer easy access. Membership in the WTO is accompanied by substantial concessions of liberalization, which have an effective impact on domestic structures. The willingness to adhere to the General Agreement on Tariffs and Trade (GATT) and the WTO as the successor organization, therefore, may be con-

57. Bundesverfassung der Schweizerischen Eidegenossenschaft [BV], [Constitution] Apr. 18, 1999, art. 190 (Switz.).

58. See, e.g., Cotrier \& Oesch, supra note 37, at 346-512. For the legal instruments, see Understanding the WTO_Principles of the Trading System, http://www.wto.org/english/thewto_e/ whatis_e/tif_e/fact2_e.htm (last visited Feb. 26, 2009). 
sidered as evidence of a true commitment to the underlying values of equal conditions of competition in international economic relations. Upon deciding to join the WTO, countries may have been compelled to accept these principles in order to promote export potentials. However, it would seem difficult to argue that members do not share the underlying value of fairness inherent in non-discrimination.

The WTO principles securing equal conditions of competition are subject to WTO dispute settlement, compensation, or trade sanctions in the case of failure to comply with rulings. While the principles are well-established, their particular contours are subject to a constant flow of case law, balancing equal conditions with other policy goals that may call for protection. As a principle, non-discrimination is established; only its operation is subject to discourse and conflict. Again, as in the case of human rights, the operation essentially depends upon efficient procedures. The same is true for other layers of governance. The protection of non-discrimination depends upon legal protection in constitutional courts and the European Court of Justice. Such protection may sometimes be even stronger at the international level than at the domestic level. In many members of the WTO, individuals and companies may not be able to invoke a corresponding constitutional right in defense of their economic interests. Similar to human rights, the emphasis in disputes is on balancing competing interests and assessing potential exemptions to these principles. We observe the same pattern: it is not a matter of questioning the legitimacy of principles of non-discrimination as basic values, but of balancing them with competing policy interests. This balance depends largely upon procedural guarantees.

In conclusion, basic principles of international economic law enjoy advanced levels of protection and implementation. This is an indication that underlying values are taken seriously and are truly shared. Procedures to arbitrate competing interests are well developed in WTO law, as well as in EU and constitutional law. Such procedures are at the heart of contemporary multilayered governance.

\section{Property Rights and Related Values}

International trade law is of interest in assessing property rights and related values. Property protection amounts to a key feature in market economies, and the way it is addressed offers insights as to the extent to which it amounts to a shared value. It is interesting to see that property, as a basic legal institution, is protected for diverging reasons and underlying values.

Real property is weakly protected in customary international law. The protection essentially applies only to arbitrary expropriation, and there are no clear 
standards for compensation. In contrast, intellectual property is subject to strong protection within the Agreement on Trade-Related Aspects of Intellectual Property Rights (TRIPs) of the WTO. ${ }^{59}$ TRIPs is an important element of multilayered governance. It amounts to a paradigm of global economic law, setting minimal standards in the field. WTO dispute settlement supports the implementation of standards, much as EC law in this field exerts a similar impact on member states of the European Union. This model of dispute settlement is anchored in law and is accompanied by efficient procedures in order to play its role in a system of multilayered governance.

While protection, in principle, may be accepted, there is considerable controversy as to whether the levels of protection provided for in TRIPs are appropriate for developing countries. TRIPs is widely conceived of as an imposed agreement, to which developing countries were forced to adhere within the package deal of the Uruguay Round. Developing countries perceive it as an imposed value, and implementation therefore faces difficulties and resistance. In practical terms, intellectual property protection in developing countries operates under a doctrine of benign neglect and is therefore subject to informal gradation. It only becomes of practical relevance in international relations to the extent that an industry achieves competitiveness. ${ }^{60}$

Patent protection is an important ingredient in establishing equal conditions of competition and thus of competition law and policy at large. It thereby forms part of the overall values enshrined in WTO law. But in the future, gradation should be formalized with a view to achieving better legal security and predictability for developing countries. ${ }^{61}$ Intellectual property protection becomes essential only once an economy starts competing and where the lack of protection causes distortions. Prior to that stage, developing countries should not be obliged to comply with demanding standards in order to foster social and economic development. But, it would seem wrong to argue that private property protection is not legitimate as a long-term investment within the WTO system. It is an essential ingredient of fostering innovation and thus contributing to welfare. Intellectual property is a utilitarian concept; it is not based upon human rights, except for some aspects of copyright. Whether it amounts to a shared or imposed value is a matter of controversy. Yet, the problem is less one of principle than one of properly shaping the contours and scope of intel-

59. See generally Frederick M. Abbott et al., International Intellectual Property in an INTEGRATEd WORLd ECONOMY (2007).

60. Cottier, supra note 55, at 6-9.

61. See Thomas Cottier, From Progressive Liberalization to Progressive Regulation, 9 J. Inr'L Econ. L. 779 (2006). 
lectual property rights, commensurate with levels of social and economic development. If properly shaped and balanced against other policy goals, intellectual property is able to serve a cosmopolitan agenda and embrace shared values, such as the promotion of health and nutrition.

A nother area of strong property protection is agriculture, in the sense that existing structures are essentially maintained and protected, or at least much more so than in any other sector of the economy. Other than in the field of intellectual property rights, equal conditions of competition are distorted by enhanced levels of border protection and domestic support on the part of industrialized countries. These levels of protection do not sufficiently take into account the impact on producers and farmers in other countries, particularly in the developing world. I submit that the protection of agricultural property in terms of preserving traditional perceptions, values of cultural diversity and identity, and sentiments of homeland depict the traditions of nationalism in political and moral philosophy.

Current policies do not yet sufficiently take into account cosmopolitan values. ${ }^{62}$ Market access for those in need of it is largely denied, at high cost to consumers and foreign producers alike. The close relationship between poverty in developing countries and conservative patterns of traditional agriculture in industrialized countries is not sufficiently clear to the public at large. The pursuit of values of equal conditions of competition implies limitations on this kind of property protection and values. There is a clash of competing values, and the difficulties experienced in trying to conclude the present Doha Development Agenda emphasize the basic tensions.

In conclusion, property protection shows different traits. Partly, it may, under appropriate conditions, amount to a cosmopolitan value, and partly it is motivated by interests and values embedded in nationalism. These values are not inherently shared by all, but imposed by some on others. But whatever their foundation, they find themselves competing with other policy goals and values. The search for appropriate regulations and implementation depends primarily upon political processes and the availability of effective dispute settlement.

\section{Conflicting Values and Moral Disagreement}

As a result, competing universal human rights values are often compromised in state practice, and the WTO reveals a mixed bag of underlying values within the broadly agreed-upon legal principles of creating equal conditions of competition for imported and domestic goods and services. Property protection cuts both ways and

62. Cottier, supra note 55 , at $9-10$. 
is motivated by different sets of values, which are partly cosmopolitan and partly nationalist. They are partly agreed upon and partly controversial and refuted. And even where they are agreed on in principle, they remain controversial when it comes to specific contours and implementation, as the fields of human rights and intellectual property show. There is no agreement as to distributive justice in international law. We are left with substantial divergence. Realists will tend to see their theories confirmed. The findings confirm a high degree of diversity and pluralism among states and the international community when it comes to implementing commonly agreed-upon rights, obligations, and underlying shared values.

The point to recall, however, is that these tensions exist similarly within the boundaries of nation. We argued that differences are matters of degree, not of principle. We find agreement on basic tenets and values, but disagreement when it comes to implementation and realization with competing interests and values. Thus, individuals disagree on the scope of human rights, in particular relating to distributive justice, and even on matters like freedom of speech. People disagree on equal conditions of competition and the scope of economic freedom and its limitations, as much as on the contours of the Four Freedoms in European Community Law. People disagree on the particular contours of patent rights, for example, in relation to genetic engineering or parallel imports. They disagree on appropriate levels of protection of agriculture in domestic and regional fora. Pluralism at home essentially builds upon disagreement.

Samantha Besson elaborated on this point in her seminal work The Morality of Conflict: Reasonable Disagreement and the Law. ${ }^{63}$ The brief discussions of human rights and economic law confirm her findings: people agree on general concepts only, but inherently disagree on specific contours of basic values such as freedom, democracy, or equality. These values are "essentially contestable concepts." ${ }^{\text {" }}$ Values and principles in law are "essentially incomplete theorised agreements." 65 They need to be made more concrete. Disagreement is the normal state of affairs in a domestic polity. People have different views and perceptions of justice: On these premises, Besson develops a theory that essentially focuses on appropriate procedures relating to discourse and decision-making. Different from ideals of consensus and deliberate democracy, she reemphasizes the need for voting ethics and majority rule ${ }^{66}$ in order

63. Samantha Besson, The Morality of Conflict: Reasonable Disagreement and the Law (2005)

64. Id. at 156,331 .

65. Id. at 331 .

66. Id. at 254 . 
to cope with conflicting values. She recognizes the need for procedural constitutional restraints for the benefit of the democratic process. ${ }^{67}$ She emphasizes the need for a carefully "balanced dialogue between the judiciary and the legislator" 68 within what she calls a model of "weak constitutionalism" in the sense that constitutions also need to be subject to revision in accordance with qualified rules. ${ }^{69}$ The main function of the law amounts to coordination of competing moral values upon which the authority of law and duties to comply rely, as well as resistance to compliance, are developed on that basis. ${ }^{70}$

These findings are immensely relevant for the doctrine of multilayered governance. Disagreement on values is present on all levels of governance. Theories claiming a special status of values of the domestic polity are refuted, and conceptual barriers between domestic and international law fall apart. The theory offers the potential for a coherent and uniform approach to values and their indeterminacies on the basis of a state of basic rational disagreement and pluralism. On all levels alike, the emphasis is on process, rather than on substance. Indeed, traditional dichotomies between constitutional law and international law may be found in the tradition of perceiving constitutions as material foundations of society, rather than as an instrument of government, the focus of which is on procedures.

In her conclusions, Besson discusses the potential of her theory for international relations as a matter of reasonable legal pluralism beyond the state level. ${ }^{71}$ The theory offers the foundation of what she calls cooperative sovereignty, ${ }^{72}$ which entails an understanding of meaningful coordination of different levels of governance, from local to global. She expounds the principles of cooperative sovereignty and of global coherence:

First of all, a revised conception of cooperative sovereignty could arise from a more elaborate approach to global legal pluralism.... Sovereignty should be conceived as a reflexive concept whose correct use is to reflect on and disagree over the values protected by sovereignty, i.e. mainly democracy and fundamental rights.... The protection of the values underlying those contestable concepts would therefore benefit more from cooperation be-

67. Id. at 317 .

68. Id. at 333 .

69. Id. at 323 .

70. Id. at 466 .

71. Id. at 534 .

72. Id. at 535 . 
tween different competent authorities and entities and how best to protect their common values and hence on when to give up sovereignty to others, than from the mere declaration of primacy of one sovereign over the other. As it is at once open and closed, cooperative sovereignty could both frame and stimulate the debates that go deep into the heart of what should be the best allocation of power and this not only in Europe, but also on a more global scale....

Secondly, cooperative sovereignty could give rise to a principle of global coherence in conditions of reasonable post- and supranational pluralism. When conflicting sovereign positions are understood as being in a cooperative relationship rather than an adversarial one, it is easy to see how a principle of respect for others' reasonable albeit different positions should be developed on the model of the principle of legal coherence at the infra-state level.... None of the conflicting sources of legality should be primarily subordinated to others and local governance should be able to coexist and flourish alongside global governance, provided conflict becomes a source of mutual learning and principled consistency in the cooperative venture of providing the common subjects to these different legal orders the values and certainty which the rule of law aims at securing for them. ${ }^{73}$

The concept thus supports what cosmopolitans seek in terms of appropriate multilevel structures with a view to optimally achieving their values. ${ }^{74}$ It essentially corresponds to the doctrine of compensatory constitutionalism, ${ }^{75}$ the doctrine of sovereignty-modern, ${ }^{76}$ and the doctrine of a five-story house. ${ }^{77}$ While supremacy of global law is the rule as an organizing principle, the latter allows for exceptions based upon the protection of human rights and fundamental values. Primacy should be defined according to a substantive rather than formal hierarchy $^{78}$ in order take into account the experience of failures of different layers of government, which need to be remedied within a system of checks and balances. All the theories share the view that allocation of powers should be looked at within an overall coherent framework with a view to bringing about the best results for the underlying values for which they stand. The existence of pluralism

73. Id. at 535-36.

74. Caney, supra note 39, at 163.

75. Anne Peters, Compensatory Constitutionalism: The Function and Potential of Fundamental International Norms and Structures, 19 LEIDEN J. INT'L L. 570 (2006).

76. Jackson, Sovereignty-Modern, supra note 30, at 785.

77. Cottier \& Hertig, supra note 24, at 261.

78. Peters, supra note 24, at 251, 306-07. 
and conflict and the absence of harmony at all layers alike, albeit to a different degree, inherently draw attention to the issues of appropriate procedures of decision-making and dispute settlement among and within different layers of governance. ${ }^{79}$ The question arises as to whether, despite differences in degree, there is a common core of values underlying debate and discourse that offers a common framework for decision-making in multilayered governance.

\section{The Quest for Common Structures and Procedures}

\section{A. Foundations}

Despite the harsh realities of a power-driven world, it is fair to say that some basic values are shared among people who, after all, share a broad range of activities and experiences in their lives. ${ }^{80}$ Wherever people go on their journey, not knowing their fate ${ }^{81}$ they are likely to concur in principle with the following values and moral obligations: respect of basic human rights; distributive justice and equity, and, in particular, satisfaction of basic needs in terms of food, shelter, clothing, and education; fairness and equal opportunity; and protection of good faith and legitimate expectation at whatever layer and form of governance they are exposed to. These values can be found in all of the world's legal cultures and religions in one expression or another. ${ }^{82}$ They are supported by moral philosophy and, increasingly, by international relations theory. They can be found in national constitutions and in international agreements, confirming a common moral ground in law. They allow one to conclude that these are truly human values of global reach and are not limited to the Western hemisphere. And to the extent that doubts exist, these values legitimately inform a normative agenda of what should be achieved in terms of shared values in a globalizing world.

These basic values provide the basis for government and process on all layers. They inform shared values in structural and procedural terms of decision-making. It is fair to conclude from human experience these basic values can best be achieved if procedural fairness, inclusiveness and participation, and reliance upon the ideals of legal protection through courts, are secured, widely shared, and form

79. Ernst-Ulrich Petersmann, From State Sovereignty to the "Sovereignty of Citizens" in the International Relations Law of the EU?, in Sovereignty in Transition 145-65 (N. Walker ed., 2003).

80. See generally A pPIAH, supra note 41.

81. RawLs, supra note 19, at 11.

82. See generally Equity in the World's Legal Systems: A Comparative Study (Ralph A. Newman ed., 1973). 
the basis of government around the world. ${ }^{83}$ The law teaches us that perhaps the most basic and shared value as a prerequisite of governance and multilayered governance is a shared belief in peaceful processes of negotiation, discourse, decisionmaking, and settlement of disputes based upon competing values and legal claims ${ }^{84}$ It offers the main basis for developing agreed-upon structures and procedures on shared levels of governance.

True, people will not necessarily agree more easily on procedures than on substance. ${ }^{85}$ Yet the situation is no different from other incomplete agreements relating to values on substance. The same pattern emerges here: there is common ground on widely shared and universally accepted values, but divergence in operation and implementation of such principles produces pluralism within common parameters. We should neither expect nor envisage uniform solutions, but instead focus on very basic tenets largely shared by people around the world. The fact that these tenets often remain incomplete, or are not implemented in many countries around the world, does not mean that they do not exist as widely shared ideals and aspirations upon which common structures can be built. Likewise, the fact that these ideals largely build upon Western traditions of statehood does not disqualify them from global reach. These traditions have underpinned the law and life of international relations for more than three hundred years and are deeply entrenched. Countries fundamentally ignoring these values fail to provide the basis for sustainable welfare and prosperity. At the same time, they offer ample variations allowing the accommodation of divergent cultural backgrounds and cultural diversity.

Identification of basic shared and existing core values underlying contemporary governmental structures may perhaps be best approached by way of exclusion. Nobody today morally endorses tyranny, dictatorship, or terror. In some parts, legitimacy is still derived from deity, and the authority of power remains highly centralized. Yet it is fair to assume that most people subject to any form of governance subscribe deep in their hearts to the protection of human rights, to the prevailing universal ideals of governance in the twenty-first century, namely, democracy and the ideal of legitimate power originating in delegation by the people and for the people within a constitutional framework. The basic values of democracy and majority rule, separation of powers and checks and balances, the rule of

83. For a discussion of trade governance, see Ernst-Ulrich Petersmann, Multilevel Judicial Governance of International Trade Requires a Common Conception of Rule of Law and Justice, in THE Future of International Economic Law, supra note 32, at 91-114.

84. Hooghe \& Marks, supra note 29.

85. This point was stressed by Andreas Føllesdal at the 2008 Kandersteg meeting. 
law, and transparency are generally agreed upon under the U.N. Charter and offer solid foundations to build upon. It is widely accepted that they provide the most stable and least unfair system of government if complemented by effective protection of human rights and, thus, of minorities. They have the best record as foundations for economic growth and welfare, as today's operating and enforced principles of equal conditions of competition demonstrate. Protection of the principles of non-discrimination can be found on all levels of government, including global law, and provide the backbone for structuring limitations to governmental discretion in the pursuit of cosmopolitan values and the protection of the interests of those who do not form part of a particular constituency and polity.

Putting all these values into operation remains a matter of politics, debate, negotiations, and the exercise of power in building structures of multilayered governance. There is ample room for differences, cultural diversity, and pluralism within a system which no longer fundamentally distinguishes between domestic, regional, and global law, but which seeks to bring about a coherent framework of governance commensurate with the process of globalization and contemporary and future challenges. General values agreed upon do not define allocation of powers, degrees of redistribution, or levels of taxation. Moral disagreement offers the starting point for addressing these issues, and compromise and coordination will need to be settled in the law of the different layers of government.

\section{B. Global Governance}

The main operational challenges will consist of finding common structures and procedures on the global level, based upon the broad values identified, and determining how these structures should influence other layers of governance. We need to work on enhanced coordination of judicial reviews in order to render vertical checks and balances fully operational and mutually supportive. Standards of review both of domestic and international courts need to be aligned and better coordinated. ${ }^{86}$ The challenges of democratic accountability and legitimacy, due process, checks and balances, the relationship of legislative and adjudicative bodies-both within a layer and among layers, and thus horizontally and verticallyand the issue of compliance deserve the most attention and elaboration in furthering the doctrine of multilayered governance. We need to work on coherent procedures for decision-making in order to coordinate efforts on different layers of government. These procedures need to go beyond modes of negotiations, to

86. Cottier \& Oesch, supra note 37 , at 513-17. 
care about decision-making even if a consensus cannot be reached. This is equally true for the layer of international relations.$^{87}$ Negotiations will be needed to hammer out solutions, implement broadly shared values, and render them operational on the level of global governance. The main issue will be majority voting and the implementation of democratic values in international decision-making.

In a multipolar world, in order to avoid a stalemate, consensus-based decisionmaking in international organizations should be backed by voting. Efficient decision-making is a corollary to the finding that values compete in operation. Workable procedures to complete agreements are essential. Traditional modes of consensus and blocking powers either relate to a false perception of uniform values or to the imposition of values by power. They depict an equality of states that does not exist in reality. They do not respond to the ideals of pluralism and democracy and the basic legitimacy of majoritarian rule. The core of shared values identified-and taking into account the global challenges shared by all, such as climate change-allow, and indeed require, further progress. We recall that the inception of democracy in nation-states was an experiment with unpredictable results; it acquired legitimacy and authority over time. It was a process and not static, but a process needing courage that was undertaken by farsighted people. ${ }^{88}$ The same is true for the process of enhancing democratic legitimacy within the European Union. A similar courageous start is required on the global level. We need to take basic and shared values of democracy seriously on all layers of governance and seek implementation in appropriate forms and modes. Only upon gaining experience with majoritarian rule can trust, confidence, and community be built within the international society.

Voting by states should be based upon weighted voting, taking into account appropriate factors, such as size of population, gross national product, international dependence (trade shares, import/export ratios), in order to approximate formal and real powers of countries and their stake and impact in international relations. ${ }^{89}$ It allows one to approximate tensions between global citizenship and representation of states. The past experience with weighted voting in the Bretton

87. In line with critical rationalism, see AlbERT, supra note 48, at 181 (arguing that the need for majority ruling goes beyond the Habermasian discourse principle which ideally relies upon negotiations and consensus); $c f$. Jüergen Habermas, Between Facts and Norms: Contributions to a Discourse Theory of Law and Democracy (1996).

88. Cf. Peters, supra note 20.

89. For a detailed calculation of potential voting rights and powers based upon such criteria at the WTO, see Thomas Cottier \& Satoko Takenoshita, Decision-making and the Balance of Powers in the WTO Negotiations: Towards Supplementary Weighted Voting, in AT the Crossronds: The World Trading System and the Doha Round 181 (Stefan Griller ed., 2008). 
Woods institutions ${ }^{90}$ does not prevent the search for more appropriate and fair allocations of voting rights and powers. In a pluralist world, decision-making will be characterized by flexible and changing coalitions, and an overall balance of industrialized, emerging, developing, and least developed economies can be achieved. At any rate, no single power and nation alone should be able, or entitled, to block decisions adopted by a majority of states. This reflects ideals of democracy and appropriate representation. It may be objected to on the grounds that majoritarian rule poses a fundamental paradox with national sovereignty and domestic democratic rule, which cannot be solved. We agree that this is true for the current, but rarely applied, principle of one state, one vote. ${ }^{91}$ Yet properly weighted voting is able to reduce tensions between representation of individuals and of states. We recall that both the protection of human rights and non-discrimination in international economic law serve the purpose of preventing and remedying state failures which may be induced by domestic majority decisions. The alloca-

90. For a critique see GarCia, supra note 42.

91. Peters, supra note 20 ("Persons are not fairly represented by the scheme 'one-state-one vote' in treaty making and for the production of secondary international law. So even if all states, "large and small' could perfectly fairly participate on an equal footing, and were in themselves perfect democracies, this would not mean democracy in the sense of global citizens' rule. On the contrary, the equality, inclusiveness and representativeness of states in international organisations are in tension with the idea of equality and representation of world citizens. Because states contain vastly different sizes of populations, there is no correlation between states' votes and citizens' votes. Equality of more populated states results in the inequality of citizens (as global citizens), and their representation is totally skewed. In that perspective, state majoritarianism is an impediment to the effective institutional expression of equal consideration of natural persons. Coordination among (more or less democratic) polities (states and international organisations democratised along the line we proposed) will frequently contradict democratic choices made within other democratic units of the network. Inter-state majoritarianism is, in a democratic perspective, ambiguous. As the ultimate reference point of democracy is natural persons, we must take into account the democratic formation of collective preferences within the nation states. We then face a paradox. In the inter-state perspective, it seems illegitimate and undemocratic that a minority (one state) can block a treaty. On the other hand, such a veto power seems necessary to preserve the democratic decision-making on the 'lower' level, within the smaller community. In that perspective, an extension of the inter-state majority principle aggravates the democratic deficit for three reasons: First, in a system of inter-state majority voting, the defeated nation's collective preferences (which have been determined through a democratic procedure) are completely ignored. When those nations' choices are based on the will of democratic majorities that are properly constituted according to the rules of their domestic arena, the decisions from 'above' will be experienced as undemocratic, even though in their own terms they were perfectly formally democratic. So in the two-level game, the question whether unanimity or majoritarian decisionmaking among states on the international plane is 'more democratic' is insoluble, if we take seriously both collectively reached decisions on both levels. But how should conflicts between two (more or less) democratically reached collective preferences be solved?"). 
tion of voting rights in the European Communities demonstrates that the relationship of international and domestic layers of governance is not fundamentally different from that in relations between central government and members of a federal state. Again, the problem of democratic legitimacy is a matter of degree, rather than of principle. Yet it is submitted that the goal and direction are correct. ${ }^{92}$ It is here that the main efforts toward coherence need to be made and achieved in institutional terms.

\section{CONCLUSION}

Multilayered governance is built, and depends, upon the identification of core values which are shared and which are able to offer a common framework for all layers equally. Whether and to what extent values are truly common can best be assessed in terms of the related procedural rights and obligations of protection and enforcement. A comparison of legal protection in human rights and international economic law shows diverging levels of protection in domestic and international law both within and between the respective fields. Procedures are key and where they are lacking, values cannot be realized. In fact, the existence of common procedures itself offers evidence of shared values. Where they are lacking, the commonality of shared values is weak or even non-existent, reduced to a formal shell. Likewise, where shared values are aspired to, we need to create appropriate procedures to protect and implement those values. Shared processes and structures of decision-making ultimately define the extent to which constitutionalization and multilayered governance exist and emerge. It is here that we face the challenge of finding more appropriate ways and means of decision-making on the global level, taking into account basic values of participation, democracy, and judicial protection. There is an ample body of values and principles relating to good governance upon which coherent structures of multilayered government can be built.

Indeed, the lessons to be learned from our observations are that the main

92. See Andrew Hurell, On Global Order: Power, Values, and the Constitution of InternaTIONAL SOCIETY 315, 318 (2004) (expressing skepticism about whether proper discourse can be found in international relations, but stressing, at the same time, the importance of process, stating "[a] revalidation of process legitimacy and procedural justice is crucial for the development of a stable, effective, and legitimate international society and for the nurturing of meaningfully shared foundations for the discussion of global justice. In a very important sense, the ethical claims of international society rest on the contention that such a society continues to be the most stable set of globally institutionalized political processes by which norms and rules can be negotiated on the basis of dialogue and consent, rather than simply being imposed by the most powerful.”); see also Hooghe \& Marks, supra note 29. 
emphasis of multilayered governance needs to be placed on structures and procedures, rather than content beyond broad, and thus incomplete, theorized agreements. Once we accept pluralism of moral values within and beyond national borders as a normal state of affairs, the bridge to overcome traditional divides between different layers of governance, including international law, is conceptually built. We need to limit the concept of shared values to very basic precepts and principles and allow ample room for pluralist variations in different contexts. We cannot expect more than very basic agreement on human values at all levels of government. The operation and implementation of these values differ widely and will continue to differ. They remain incomplete and controversial within societies and among societies. They offer a common ground, but are subject to different outcomes and sometimes to disrespect, as practical solutions result in competition of diverging values and rights. Inherently, they result in a pluralist and inconsistent landscape in different societies and on different layers of governance. This is true both in substance and in procedural terms. Societies and states continue to vary and have particularities even with shared values and common layers of governance. Shared values, in other words, do not prevent or exclude diversity. They do not render the world a flat place, devoid of cultural differences. ${ }^{93}$ Globalization is not just about uniformity; it is as much about interaction that is complementary to divergence and diversity. International law is not simply about harmonization and uniformity; it is equally about protecting legitimate cultural divergence. ${ }^{94}$ The same is true of regional law, in particular in the European Union. It is equally a common trait and purpose of federalist structures.

On these premises, nothing prevents building upon human experience in the legal process and bridging the divide between domestic and international law. The approach is suitable beyond the realm of cosmopolitanism. It may embrace different schools of thought, such as the idea of a society of states, of cultural relativism, even of realism to the extent that these schools agree on very basic traits of the human condition and on structures of democratic government in a pluralist society where most is left to debate, the political process, negotiations and the settlement of disputes. It offers the foundations upon which the quest for appropriate structures and procedures within a comprehensive doctrine of multilayered governance can be built in the coming decades.

93. Contra Thomas L. Friedman, The World is Flat: A Brief History of the Twenty-First Century (2005).

94. Christoph Beat Graber, Handel und Kultur im Audiovisionsrecht der WTO 100-08 (2003). 


\section{Indiana University Press/Journals}

\section{Race/Ethnicity Multidisciplinary Global Contexts}

A peer-reviewed journal jointly produced through The Kirwin Institute for the Study of Race and Ethnicity and the Office of Minority Affairs at The Ohio State University

PUBLISHED SEMIANNUALLY eISSN 1935-8562 pISSN 1935-8644

800-842-6796 812-855-8817

http://inscribe.iupress.org

Available in electronic, combined electronic \& print, and print formats

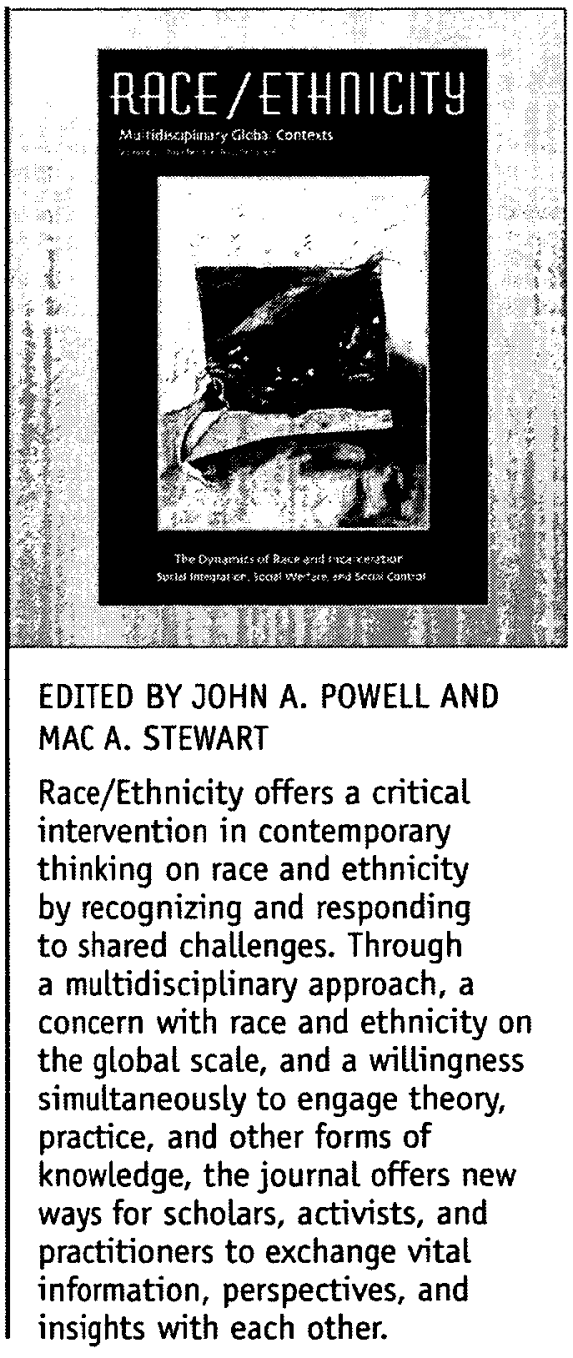

\section{IJ $\mid$\begin{tabular}{|l} 
INDIANA UNIVERSITY PRESS \\
\hline INDIANA UNIYERSITY
\end{tabular}}

601 North Morton Street, Bloomington, Indiana 47404-3797 USA 